\title{
Diet-Induced Thermogenesis and Expression Levels of Thyroid Hormone Target Genes and Their Products in Rats Differ between Meat Proteins
}

\author{
Misako EzoE $^{1,2}$, Jun-ichi WAKAMATsU ${ }^{1, *}$, Yoshihisa TAKAHATA ${ }^{2}$, \\ Takanori HASEGAWA $^{2}$, Fumiki Morimatsu ${ }^{2}$ and Takanori NiSHIMURA ${ }^{1}$ \\ ${ }^{1}$ Graduate School of Agriculture, Hokkaido University, Kita 9 Nishi 9, Kita-ku, \\ Sapporo, Hokkaido 060-8589, Japan \\ ${ }^{2} R$ \& D Center, Nippon Meat Packer, Inc., 3-3, Midorigahara, Tsukuba, Ibaraki 300-2646, Japan
}

(Received March 25, 2015)

\begin{abstract}
Summary We compared the effects of purified meat proteins on postprandial thermogenesis and on the secretion of and responsiveness to thyroid hormones (THs) in rats. Body temperatures at $2 \mathrm{~h}$ after feeding were significantly higher in the chicken and mutton protein groups than in the other groups, and these proteins seem to have a strong thermogenic effect. There were no significant differences in plasma TH concentrations among the groups, but levels of TH-responsive Spot 14 protein in the liver and brown adipose tissue were significantly higher in the chicken and mutton protein groups than in the other groups. Levels of malic enzyme 1 protein in the liver and brown adipose tissue were significantly higher in the chicken protein group than in the other groups except for the mutton protein group. Furthermore, levels of uncoupling protein 1 were higher in the chicken and mutton protein groups than in the other groups. The results suggest that the difference in postprandial thermogenesis of meat is strongly dependent on meat proteins; chicken and mutton proteins are strong promoters of postprandial thermogenesis, and THs may contribute to this effect. Since strong postprandial thermogenesis and high expression levels of TH target genes and their products were not observed in the amino acid group, chicken and mutton proteins or their digested peptides might contribute to these effects.
\end{abstract}

Key Words meat protein, diet-induced thermogenesis, brown adipose tissue, thyroid hormone target gene, UCP1

Daily energy expenditure consists of basal metabolic rate, energy cost of physical activity, and diet-induced thermogenesis (DIT). DIT can be defined as heat production due to consumption of a meal, and its magnitude depends on the components of the food, not the energy content of the food $(1,2)$. Proteins have a larger DIT effect than do carbohydrates or lipids (1-5). Since enhancement of DIT can suppress obesity (6), various foods and their ingredients that enhance DIT have been widely studied. For example, red peppers have a large DIT effect due in part to capsaicin (6-8). Green tea also has a large DIT effect due in part to catechins and caffeine $(6,7,9)$. Capsaicin, catechins, and caffeine promote DIT by stimulating lipolysis and enhancing the function of brown adipose tissue (BAT), which has an important role in heat production (6-9).

Our previous studies showed that the DIT effects of meat vary depending on the source species: chicken and mutton have stronger DIT effects than those of pork and beef. Even when chicken and mutton were fractionated, the protein fractions showed strong DIT effects comparable to those of chicken and mutton $(10,11)$. The differences in the DIT effects of meats may be caused

\footnotetext{
*Corresponding author.

E-mail: jwaka@anim.agr.hokudai.ac.jp
}

by differences in meat proteins. However, to our knowledge, there has been no study on the DIT effects of meat proteins of other animal species.

Body temperature in homeothermic animals is mainly regulated by hormones such as adrenaline, noradrenaline, corticosteroids, and thyroid hormones (THs). Capsaicin acts on the brain stem and promotes the secretion of adrenaline from the adrenal medulla, resulting in a strong DIT effect (6-8). In contrast, the strong DIT effect of chicken and mutton might be due to stimulation of the secretion of THs rather than stimulation of the secretion of adrenaline $(10,11)$. The THs triiodothyronine $\left(\mathrm{T}_{3}\right)$ and thyroxine $\left(\mathrm{T}_{4}\right)$ play important roles in metabolic control and regulate whole-body thermogenesis, particularly basal metabolism $(12,13)$. Both $\mathrm{T}_{3}$ and $\mathrm{T}_{4}$ bind to intracellular receptors ( $\mathrm{TH}$ receptors) to regulate the transcription of genes involved in metabolism and thermogenesis $(14,15)$. Genes that are markedly induced by THs include genes encoding TH-responsive Spot 14 protein (THRSP), malic enzyme 1 (ME1), and uncoupling protein 1 (UCP1) (14-17). Moreover, it has been shown that $\mathrm{T}_{3}$ and $\mathrm{T}_{4}$ enhanced thermogenesis in BAT by promoting Ucp1 gene expression (14, 17). A number of studies have been carried out on the effects of THs on DIT $(18-20)$. The results of the abovedescribed studies indicate that the differences in the 
Table 1. Amino acid compositions of purified meat proteins and amino acid mixture

\begin{tabular}{|c|c|c|c|c|c|c|}
\hline & \multicolumn{5}{|c|}{ Purified meat protein } & \multirow{2}{*}{$\mathrm{AA}^{*, \dagger}$} \\
\hline & $\mathrm{CP}^{*}$ & $\mathrm{MP}^{*}$ & $\mathrm{PP}^{*}$ & $\mathrm{BP}^{*}$ & $\mathrm{HP}^{*}$ & \\
\hline \multicolumn{7}{|c|}{ Amino acid, $\%$} \\
\hline Asp & 10.0 & 9.6 & 10.1 & 9.9 & 9.9 & 9.5 \\
\hline Thr & 4.9 & 4.9 & 4.9 & 4.8 & 4.9 & 4.8 \\
\hline Ser & 4.3 & 4.3 & 4.3 & 4.2 & 4.3 & 4.1 \\
\hline Glu & 15.8 & 16.2 & 15.8 & 16.0 & 16.0 & 15.8 \\
\hline Gly & 4.2 & 4.4 & 4.2 & 4.9 & 4.1 & 4.7 \\
\hline Ala & 5.9 & 6.0 & 5.9 & 6.2 & 5.9 & 5.9 \\
\hline Cys & 0.0 & 0.1 & 0.1 & 0.1 & 0.1 & 1.2 \\
\hline Val & 5.1 & 5.1 & 5.3 & 5.1 & 5.1 & 5.1 \\
\hline Met & 3.1 & 2.9 & 3.0 & 2.9 & 2.8 & 2.8 \\
\hline Ile & 5.2 & 4.9 & 5.1 & 5.0 & 5.0 & 4.8 \\
\hline Leu & 8.7 & 8.9 & 8.8 & 8.9 & 9.1 & 8.3 \\
\hline Tyr & 3.8 & 3.8 & 3.8 & 3.7 & 3.9 & 3.6 \\
\hline Phe & 4.4 & 4.4 & 4.4 & 4.4 & 4.6 & 4.1 \\
\hline Lys & 9.6 & 9.7 & 9.6 & 9.1 & 9.6 & 9.3 \\
\hline His & 2.8 & 2.8 & 2.8 & 2.8 & 2.9 & 4.4 \\
\hline Trp & 0.8 & 0.8 & 0.8 & 0.7 & 0.8 & 1.1 \\
\hline Arg & 7.3 & 7.1 & 7.0 & 7.0 & 7.0 & 6.6 \\
\hline Pro & 4.0 & 4.2 & 4.0 & 4.3 & 4.2 & 4.0 \\
\hline
\end{tabular}

${ }^{*} \mathrm{CP}$ : chicken protein, MP: mutton protein, PP: pork protein, BP: beef protein, HP: horse meat protein, AA: amino acids.

${ }^{\dagger}$ Amino acid ratio is based on the average value of amino acid compositions of five kinds of lean meat (chicken, mutton, pork, beef and horse meat) described in Standard Tables of Food Composition in Japan 2010.

effects of meat on DIT might be caused by differences in the effects of meat proteins on the secretion and responsiveness of THs.

To determine whether the differences in effects of meat on DIT are caused by differences in meat proteins, we compared the body temperatures of rats that were fed diets containing different meat proteins. With a focus on THs and their responsiveness, we also compared the expression levels of TH target genes and their translation products in the liver and BAT, both of which are major heat-producing tissues in the body at rest.

\section{MATERIALS AND METHODS}

Animals and diets. This study was approved by the Laboratory Animal Care Committee of Hokkaido University. The experiment was carried out as in our previous study (10). Five-week-old male Wistar rats were purchased from Japan Laboratory Animals Inc. (Tokyo, Japan). The rats were housed individually in stainless steel cages with a 12-h light-dark cycle (lights on from 10:00 to 22:00) in an isolated room at a temperature of $22-24^{\circ} \mathrm{C}$ and humidity of $40-60 \%$. For 1 wk before the experiment, all of the rats were acclimatized to an AIN-93G diet (using corn oil in place of soybean oil). The rats had free access to feed and water.

Chicken legs, mutton hind legs, pork outside round, beef bottom round, and horse round meat were pur-
Table 2. Compositions of the experimental diets.

\begin{tabular}{|c|c|c|c|c|c|c|}
\hline & \multicolumn{5}{|c|}{ Diet } & \multirow{2}{*}{$\mathrm{AA}^{*}$} \\
\hline & $\mathrm{CP}^{*}$ & $\mathrm{MP}^{*}$ & $\mathrm{PP}^{*}$ & $\mathrm{BP}^{*}$ & $\mathrm{HP}^{*}$ & \\
\hline \multicolumn{7}{|l|}{ Ingredient, \% } \\
\hline $\mathrm{CP}^{*}$ & 17.4 & - & - & - & - & - \\
\hline $\mathrm{MP}^{*}$ & - & 18.1 & - & - & - & - \\
\hline $\mathrm{PP}^{*}$ & - & - & 18.0 & - & - & - \\
\hline $\mathrm{BP}^{*}$ & - & - & - & 17.9 & - & - \\
\hline $\mathrm{HP}^{*}$ & - & - & - & - & 18.1 & - \\
\hline $\mathrm{AA}^{*}$ & - & - & - & - & - & 19.5 \\
\hline Corn oil & 7.0 & 7.0 & 7.0 & 7.0 & 7.0 & 7.0 \\
\hline Corn starch & 55.5 & 54.9 & 55.0 & 55.1 & 54.9 & 53.4 \\
\hline \multicolumn{7}{|l|}{ Nutrient, \% } \\
\hline Total protein & 17.3 & 17.3 & 17.3 & 17.3 & 17.3 & 17.3 \\
\hline Total fat & 7.0 & 7.0 & 7.0 & 7.0 & 7.0 & 7.0 \\
\hline \multicolumn{7}{|c|}{$\begin{array}{l}\text { Other constituents common to both diets include cel- } \\
\text { lulose }(5 \%) \text {, sucrose }(10 \%) \text {, L-cystine }(0.3 \%) \text {, mineral } \\
\text { mix }(3.5 \%) \text {, vitamin mix }(0.1 \%) \text {, and choline bitartrate } \\
(0.25 \%) \text {. Vitamin and mineral mixes were formulated } \\
\text { according to AIN-93G. Diet components were purchased } \\
\text { from CLEA Japan, Inc., Tokyo, Japan. } \\
\text { * CP, chicken protein; MP, mutton protein; PP, pork pro- } \\
\text { tein; BP, beef protein; HP, horse meat protein; AA, amino } \\
\text { acids. }\end{array}$} \\
\hline
\end{tabular}

chased from a domestic market. Proteins in the meat were purified as described previously (10). First, as much fat and connective tissue as possible were removed, and then the meat was ground and freezedried. The freeze-dried meat was defatted with $n$-hexane and then washed with hot ethanol and boiling water. The protein contents of each preparation, calculated from the $\mathrm{N}$ content determined by the Kjeldahl method, were $99.2 \%$ for chicken protein (CP), $95.8 \%$ for mutton protein (MP), 96.3\% for pork protein (PP), 96.9\% for beef protein (BP), and $95.6 \%$ for horse meat protein (HP). Amino acid composition analysis of the purified protein was outsourced to Instrumental Analysis Division, Equipment Management Center, Creative Research Institution, Hokkaido University (ninhydrin method after hydrolysis with $3 \mathrm{M}$ mercaptoethanesulfonic acid at $110^{\circ} \mathrm{C}$ for $22 \mathrm{~h}$; Table 1 ). We mixed amino acids (AA) on the basis of the composition of these lean meats (Standard Tables of Food Composition in Japan 2010 (21), Table 1), creating a preparation with a protein content of $88.5 \%$. Using each preparation, we prepared AIN-93G diets (using corn oil) with the same contents of protein and fat (Table 2). After fasting for $18 \mathrm{~h}$, the rats were fed the experimental diets $(7 \mathrm{~g} / \mathrm{animal})$ in the last $1 \mathrm{~h}$ of the dark cycle (from 22:00 to 10:00).

Measurements of body weight and body temperature. Eighteen rats were prepared as described previously (10). Immediately after feeding for $1 \mathrm{~h}$, the rats were anesthetized with an intraperitoneal injection of urethane $(700 \mathrm{mg} / \mathrm{kg})$ and $\alpha$-chloralose $(60 \mathrm{mg} / \mathrm{kg})$, and body weights were measured ("immediately after feeding" $=0 \mathrm{~h}$ ). To exclude the effect of heat loss, temperature 

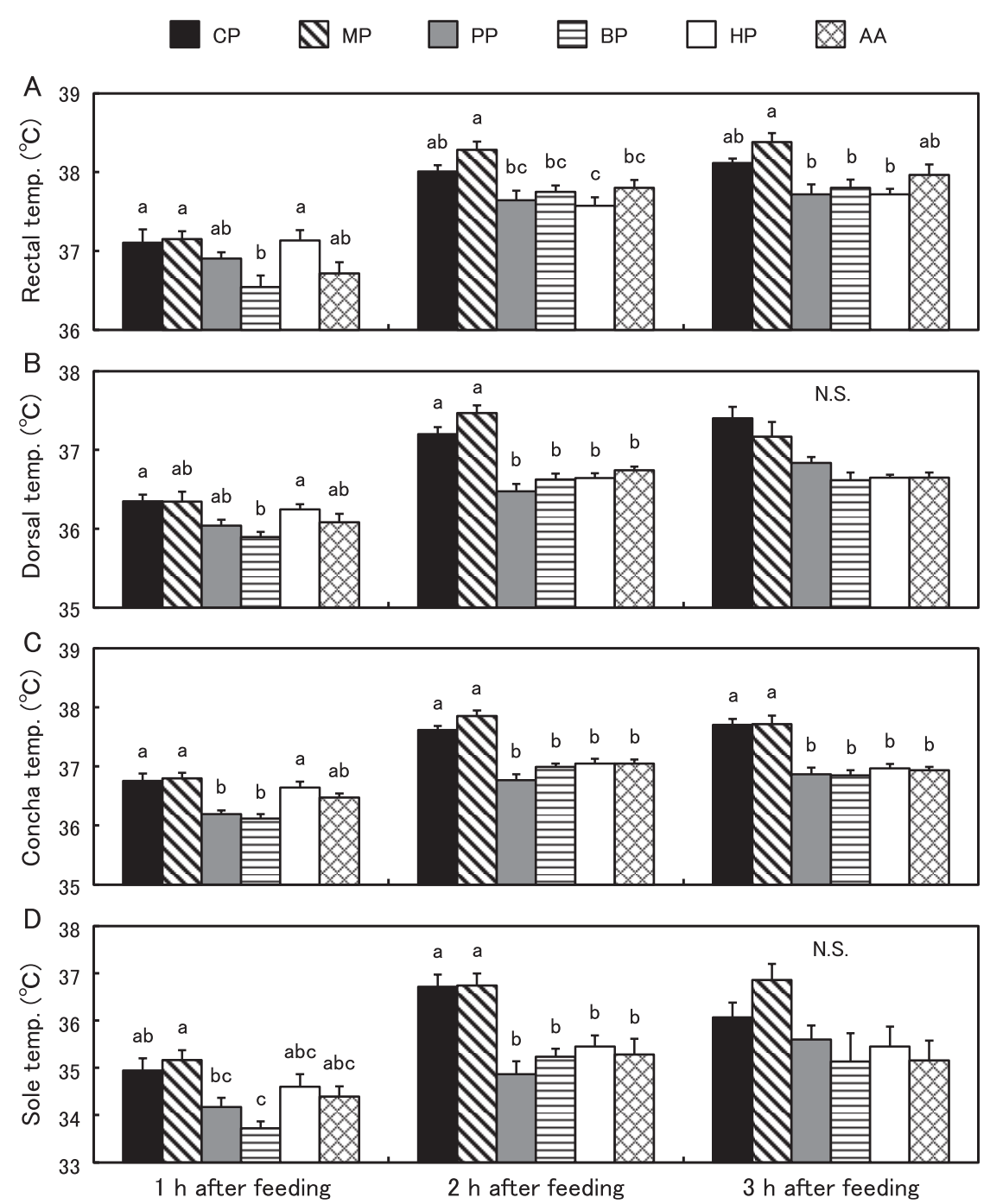

Fig. 1. Changes in postprandial body temperatures (A, rectal; B, dorsal; C, concha; D, sole) of rats fed diets containing purified meat protein (CP, chicken protein; MP, mutton protein; PP, pork protein; BP, beef protein; HP, horse meat protein) or amino acids (AA) after feeding for $1 \mathrm{~h}$. Values are means \pm SEM $(1,2$ and $3 \mathrm{~h}$ after feeding; $n=18,12$, and 6 rats per group, respectively). Columns with different letters are significantly different ( $p<0.05$; Tukey's multiple comparison test).

was measured on a thermostatic plate $\left(33^{\circ} \mathrm{C}, \mathrm{KN}-210-6\right.$, Natsume Seisakusho Co. Ltd., Tokyo, Japan) in a room at a controlled temperature of $33^{\circ} \mathrm{C}$. To measure rectal temperature, we gently inserted a glycerol-dipped thermocouple $2 \mathrm{~cm}$ into the rectum (1600K-T21-ASP, Anritsu Meter Co. Ltd., Tokyo, Japan) and read the temperature on a CT-1307 thermometer (Custom, Tokyo, Japan). The back hair was clipped short and the dorsal temperature was measured at the interscapular area with an infrared thermometer (IT-550, Horiba Ltd., Kyoto, Japan). Concha and sole temperatures were also measured with an infrared thermometer.

Immediately after each hourly measurement of body temperature, six anesthetized rats were bled out through the inferior vena cava, and blood was collected into plastic tubes containing EDTA $(2 \mathrm{mg} / \mathrm{mL})$. The right lobe of the liver and interscapular BAT were then removed and immediately frozen in liquid nitrogen. Plasma was separated from the blood by centrifugation, and all plasma and tissue samples were stored at $-80^{\circ} \mathrm{C}$ until analysis.
Analysis of thyroid hormones in plasma. Total levels of $\mathrm{T}_{3}$ and $\mathrm{T}_{4}$ in plasma were measured using the ECLIA (electrochemiluminescent immunoassay) method by a clinical laboratory testing service (SRL Inc., Tokyo, Japan).

RNA extraction and quantitative real-time PCR. Total RNA was extracted from the liver and BAT with ISOGEN II reagent (Nippon Gene Co. Ltd., Tokyo, Japan), and $1 \mu \mathrm{g}$ of RNA was reverse-transcribed with a Transcriptor FirstStrand cDNA Synthesis Kit (Roche Diagnostics GmbH, Mannheim, Germany) to generate cDNA (11). Real-time PCR was performed with $2 \mu \mathrm{L}$ of cDNA in a LightCycler FastStart DNA MasterPLUS SYBR Green I Kit (Roche Diagnostics) using the following primers: for Thrsp, F 5'-GAGCCCCCGATCTCTATACC-3' and R 5'-GGCTTCTAGGTCCAGCTCCT-3'; for Me1, F 5'-AGGCCTCTTTATCAGTATCCAC-3' and R 5'-CCATCCCGTTACAACCAA-3'; for Ucp1, F 5'-CCACATAGGCGACTTGGA-3' and $\mathrm{R}$ 5'-TTCGTGGTCTCCCAGCATAG-3'; and for $\beta$-actin (Actb), F 5'-AGCCATGTACGTAGCCATCC-3' and 
Table 3. Food intake during $1 \mathrm{~h}$ of feeding and body weights of each group of rats fed the experimental diets.

\begin{tabular}{|c|c|c|c|c|c|c|c|}
\hline & $\mathrm{CP}^{*}$ & $\mathrm{MP}^{*}$ & $\mathrm{PP}^{*}$ & $\mathrm{BP}^{*}$ & $\mathrm{HP}^{*}$ & $\mathrm{AA}^{*}$ & $\begin{array}{c}\text { Significant } \\
\text { difference }\end{array}$ \\
\hline \multicolumn{8}{|c|}{ Food intake, $g$} \\
\hline $1 \mathrm{~h}^{\dagger}$ & $3.98 \pm 0.25$ & $4.68 \pm 0.52$ & $4.42 \pm 0.40$ & $4.95 \pm 0.13$ & $4.37 \pm 0.40$ & $3.48 \pm 0.48$ & N.S. \\
\hline $2 \mathrm{~h}^{\dagger}$ & $4.68 \pm 0.46$ & $3.98 \pm 0.50$ & $4.55 \pm 0.62$ & $4.30 \pm 0.33$ & $4.15 \pm 0.40$ & $3.93 \pm 0.32$ & N.S. \\
\hline $3 \mathrm{~h}^{\dagger}$ & $5.00 \pm 0.48$ & $4.78 \pm 0.36$ & $4.55 \pm 0.24$ & $4.50 \pm 0.47$ & $4.52 \pm 0.52$ & $3.47 \pm 0.20$ & N.S. \\
\hline \multicolumn{8}{|c|}{ Body weight, g } \\
\hline $1 \mathrm{~h}^{\dagger}$ & $184.5 \pm 3.4$ & $182.1 \pm 1.4$ & $184.9 \pm 1.3$ & $180.4 \pm 2.2$ & $179.3 \pm 3.0$ & $185.9 \pm 3.1$ & N.S. \\
\hline $2 \mathrm{~h}^{\dagger}$ & $182.4 \pm 2.2$ & $180.5 \pm 1.8$ & $183.4 \pm 1.7$ & $179.3 \pm 5.4$ & $181.4 \pm 1.9$ & $186.1 \pm 3.0$ & N.S. \\
\hline $3 \mathrm{~h}^{\dagger}$ & $187.4 \pm 2.2$ & $182.2 \pm 1.5$ & $186.8 \pm 3.6$ & $181.8 \pm 3.1$ & $178.2 \pm 3.1$ & $182.0 \pm 2.8$ & N.S. \\
\hline
\end{tabular}

Values are means \pm SEM $(n=6$ rats per group).

* CP, chicken protein; MP, mutton protein; PP, pork protein; BP, beef protein; HP, horse meat protein; AA, amino acids.

$\dagger$ Elapsed time after feeding.

Table 4. Plasma $\mathrm{T}_{3}$ and $\mathrm{T}_{4}$ levels in rats fed the experimental diets.

\begin{tabular}{|c|c|c|c|c|c|c|}
\hline & $\mathrm{CP}^{*}$ & MP* & $\mathrm{PP}^{*}$ & $\mathrm{BP}^{*}$ & $\mathrm{HP}^{*}$ & $\mathrm{AA}^{*}$ \\
\hline \multicolumn{7}{|c|}{$\mathrm{T}_{3}, \mathrm{ng} / \mathrm{mL}$} \\
\hline $1 \mathrm{~h}^{\dagger}$ & $1.11 \pm 0.04$ & $1.12 \pm 0.05$ & $1.11 \pm 0.04$ & $1.11 \pm 0.04$ & $1.16 \pm 0.03^{\mathrm{a}}$ & $1.24 \pm 0.06$ \\
\hline $2 \mathrm{~h}^{\dagger}$ & $1.08 \pm 0.04$ & $1.14 \pm 0.05$ & $1.14 \pm 0.03$ & $1.09 \pm 0.03$ & $1.06 \pm 0.04^{b}$ & $1.07 \pm 0.06$ \\
\hline \multicolumn{7}{|c|}{$\mathrm{T}_{4}, \mu \mathrm{g} / \mathrm{dL}$} \\
\hline $1 \mathrm{~h}^{\dagger}$ & $4.21 \pm 0.22^{\mathrm{a}}$ & $4.26 \pm 0.30$ & $3.90 \pm 0.23$ & $3.65 \pm 0.22$ & $3.76 \pm 0.14$ & $4.35 \pm 0.25^{\mathrm{a}}$ \\
\hline $2 \mathrm{~h}^{\dagger}$ & $3.45 \pm 0.13^{b}$ & $3.71 \pm 0.23$ & $3.94 \pm 0.19$ & $3.47 \pm 0.22$ & $3.55 \pm 0.16$ & $3.34 \pm 0.14^{b}$ \\
\hline
\end{tabular}

Values are means \pm SEM ( $n=6$ rats per group). Columns with different letters are significantly different between 1 and $2 \mathrm{~h}$ within the same group $(p<0.05)$.

${ }^{*}$ CP, chicken protein; MP, mutton protein; PP, pork protein; BP, beef protein; HP, horse meat protein; AA, amino acids.

† Elapsed time after feeding.

R 5'-CTCTCAGCTGTGGTGGTGAA-3'. The PCR conditions for amplification were 45 cycles of denaturation at $95^{\circ} \mathrm{C}$ for $10 \mathrm{~s}$; annealing at $56^{\circ} \mathrm{C}(\mathrm{Thrsp}), 52^{\circ} \mathrm{C}(\mathrm{Me} 1)$, $55^{\circ} \mathrm{C}(\mathrm{Ucp} 1)$, or $54^{\circ} \mathrm{C}($ Actb) for $5 \mathrm{~s}$; and extension at $72^{\circ} \mathrm{C}$ for $10 \mathrm{~s}$.

SDS-PAGE and Western blotting. For extraction of proteins, each liver and BAT sample was homogenized in an extraction buffer containing $50 \mathrm{~mm}$ Tris $\cdot \mathrm{HCl}$ (pH 6.8), 20\% glycerol, 1\% 2-mercaptoethanol, and $1 \%$ SDS (liver) or $2 \%$ SDS (BAT) and then heated at $105^{\circ} \mathrm{C}$ for $5 \mathrm{~min}$ to denature the proteins. Each extract was centrifuged at $2,070 \times g$ for $10 \mathrm{~min}\left(4^{\circ} \mathrm{C}\right)$, and the supernatants were collected. Each sample was separated in $12.5 \%$ SDS-polyacrylamide gel, and the separated proteins were transferred onto Hybond ${ }^{\mathrm{TM}}$-P PVDF membranes ( 30 V, 30 min; General Electric Company, Fairfield, CT). After brief washing in T-PBS (137 mM NaCl, $2.68 \mathrm{mM} \mathrm{KCl}, 8.10 \mathrm{mM} \mathrm{Na}_{2} \mathrm{HPO}_{4}, 1.47 \mathrm{mM} \mathrm{KH}_{2} \mathrm{PO}_{4}$, $0.1 \%$ Tween 20 , unadjusted $\mathrm{pH}$ ), the membranes were blocked with $0.5 \%$ skim milk in T-PBS for $1.5 \mathrm{~h}$ at room temperature. The membranes were then incubated for $1 \mathrm{~h}$ at room temperature with primary antibodies in blocking buffer: rabbit polyclonal antibodies against THRSP (1/200 for liver, 1/150 for BAT; Santa Cruz Biotechnology Inc., Dallas, TX), ME1 (1/300 for liver, 1/500 for BAT; Santa Cruz Biotechnology), UCP1
(1/1,000 for BAT; AnaSpec Inc., Fremont, CA), and $\beta$-actin (1/1,000 for liver, 1/500 for BAT; AnaSpec). After washes in T-PBS, the membranes were incubated for $2 \mathrm{~h}$ at room temperature with horseradish peroxidase-conjugated anti-rabbit IgG $(\mathrm{H}+\mathrm{L})$ secondary antibody (1/10,000; Chemicon International Inc., Billerica, MA) in blocking buffer. After further washes in T-PBS, the membranes were treated with chemiluminescence detection reagents (Chemi-Lumi One L, Nacalai Tesque Inc., Kyoto, Japan), and immunoreactive protein bands were visualized in a ChemiDoc ${ }^{\mathrm{TM}}$ XRS Plus System and analyzed by Image Lab ${ }^{\mathrm{TM}}$ software (both from Bio-Rad Laboratories Inc., Hercules, CA).

Statistical analysis. Values are given as means \pm SEM. All data were analyzed by parametric one-way analysis of variance (ANOVA) and then by Tukey's multiple comparison test when appropriate (Excel Toukei 2006, Social Survey Research Information Co., Ltd., Japan). A $p$ value of $<0.05$ was considered statistically significant.

\section{RESULTS}

Postprandial changes in body temperatures of rats fed the experimental diets

All body temperatures in each of the feeding groups approached their peaks at $2 \mathrm{~h}$ after feeding, and dorsal, concha, and sole temperatures were significantly higher 
A
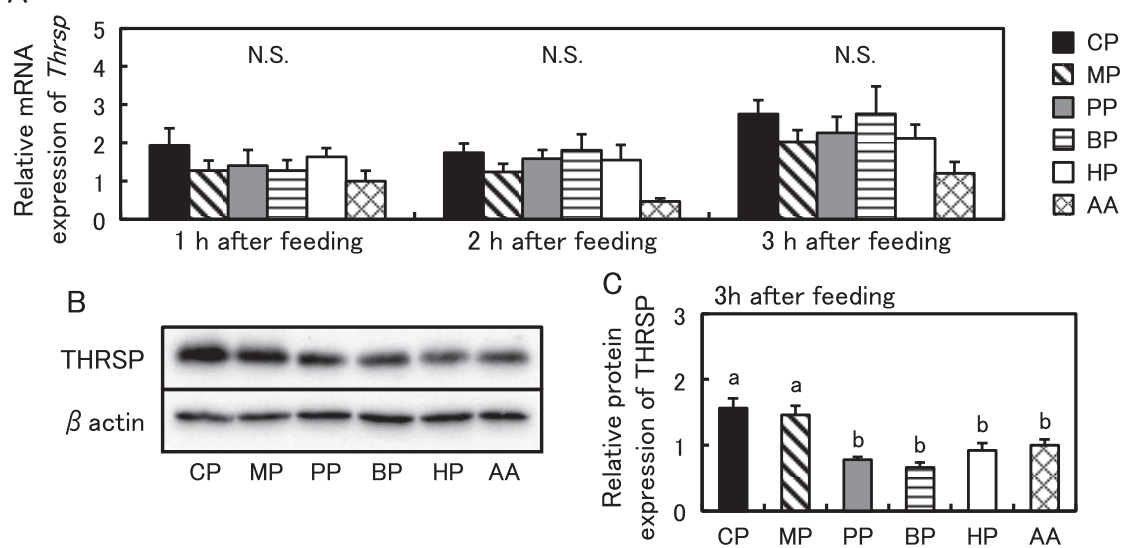

D
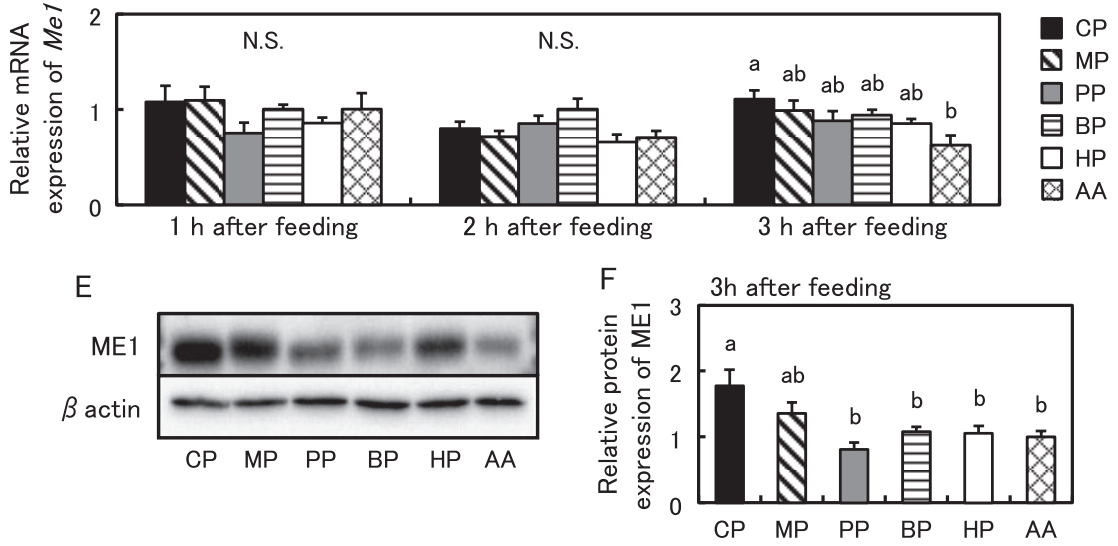

Fig. 2. Effects of meat protein diets (CP, chicken protein; MP, mutton protein; PP, pork protein; BP, beef protein; HP, horse meat protein) on the expression of thyroid hormone target genes and their translation products in the rat liver. A, relative expression of thyroid hormone-responsive Spot 14 protein (THRSP) mRNA; B, representative bands of THRSP; C, relative production of THRSP; D, relative expression of malic enzyme 1 (ME1) mRNA; E, representative bands of ME1 protein; F, relative production of ME1 protein. Samples were collected at 1, 2, and $3 \mathrm{~h}$ after feeding for $1 \mathrm{~h}$. Values are normalized to $\beta$-actin. Values are means \pm SEM ( $n=6$ rats per group). Columns with different letters are significantly different $(p<0.05$; Tukey's multiple comparison test).

in the $\mathrm{CP}$ and MP groups than in the other groups (Fig. $1 \mathrm{~A}-\mathrm{D})$. The high concha temperatures in the $\mathrm{CP}$ and MP groups were maintained at $3 \mathrm{~h}$ after feeding. All body temperatures in the AA group were as low as those in the PP, BP, and HP groups. There were no significant differences in food intake or body weight among the groups (Table 3).

Plasma $T_{3}$ and $T_{4}$ levels in rats

Levels of $\mathrm{T}_{3}$ and $\mathrm{T}_{4}$ did not differ significantly among the groups at 1 or $2 \mathrm{~h}$ after feeding (Table 4). However, the level of $\mathrm{T}_{3}$ at $1 \mathrm{~h}$ after feeding was significantly higher than that at $2 \mathrm{~h}$ after feeding in the HP group, and the level of $\mathrm{T}_{4}$ at $1 \mathrm{~h}$ after feeding was significantly higher than that at $2 \mathrm{~h}$ after feeding in the $\mathrm{CP}$ and $\mathrm{AA}$ groups.

Levels of thyroid hormone target genes and translation products in the liver

The levels of Thrsp mRNA at 1, 2, and $3 \mathrm{~h}$ after feeding were not significantly different among the groups (Fig. 2A). However, the level of THRSP protein at $3 \mathrm{~h}$ after feeding was significantly higher in the $\mathrm{CP}$ and $\mathrm{MP}$ groups than in the other groups (Fig. 2B, C). The levels of Me1 mRNA at 1 and $2 \mathrm{~h}$ after feeding were not significantly different among the groups, but the level at $3 \mathrm{~h}$ after feeding was significantly higher in the $\mathrm{CP}$ group than in the AA group (Fig. 2D). The level of ME1 protein at $3 \mathrm{~h}$ after feeding in the $\mathrm{CP}$ group was significantly higher than that in the other groups except for the MP group (Fig. 2E, F).

Levels of thyroid hormone target genes and translation products in BAT

The level of Thrsp mRNA at $1 \mathrm{~h}$ after feeding was significantly higher and the levels at 2 and $3 \mathrm{~h}$ after feeding tended to be higher, in the MP group than in the other groups (Fig. 3A). The level of THRSP protein at $3 \mathrm{~h}$ after feeding was significantly higher in the $\mathrm{CP}$ and $\mathrm{MP}$ groups than in the other groups (Fig. 3B, C). The levels of Me1 mRNA at 1, 2, and $3 \mathrm{~h}$ after feeding were not significantly different among the groups (Fig. 3D). However, the level of ME1 protein at $3 \mathrm{~h}$ after feeding was significantly higher in the $\mathrm{CP}$ group than in the other groups except for the MP group (Fig. 3E, F). The levels of Ucp $1 \mathrm{mRNA}$ at 1, 2, and $3 \mathrm{~h}$ after feeding were not significantly different among the groups (Fig. 3G). However, the level of UCP1 protein at $3 \mathrm{~h}$ after feeding was significantly higher in the $\mathrm{CP}$ and MP groups than in the 
A

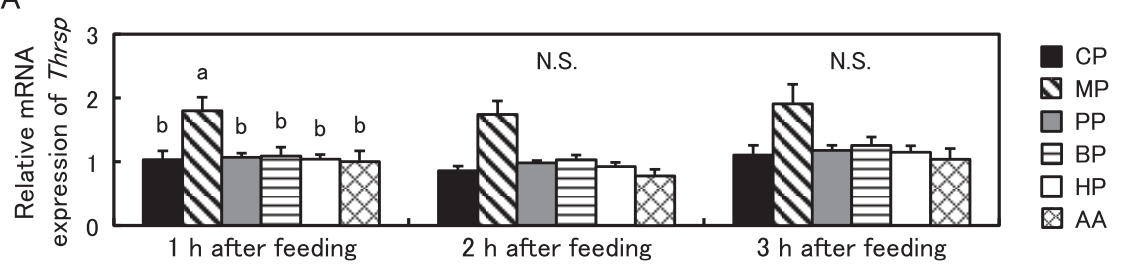

B

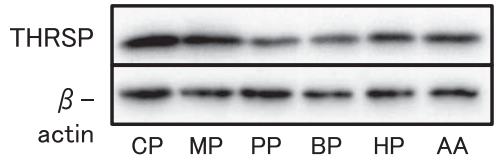

$C$ क 3 h after feeding

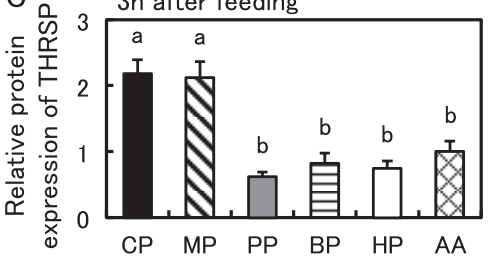

D

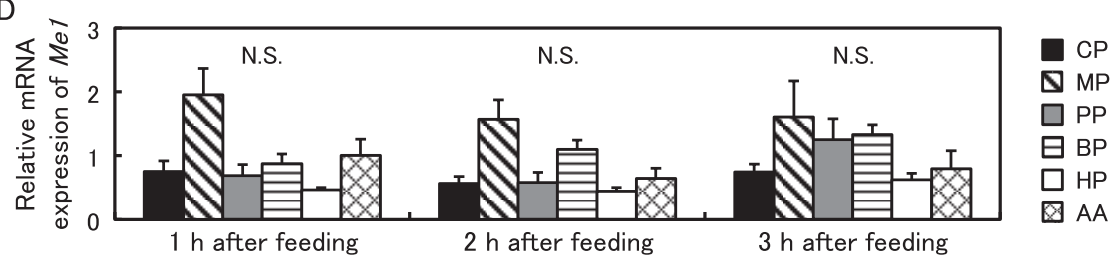

$\mathrm{E}$

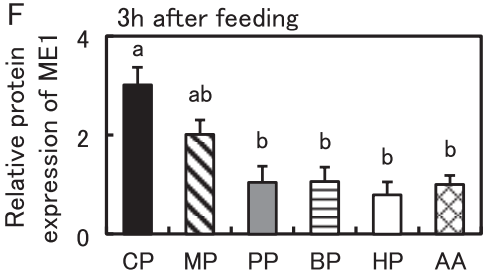

$\mathrm{G}$

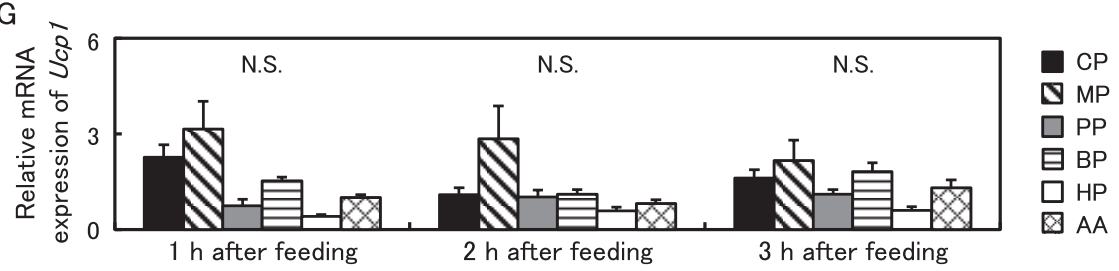

$\mathrm{H}$

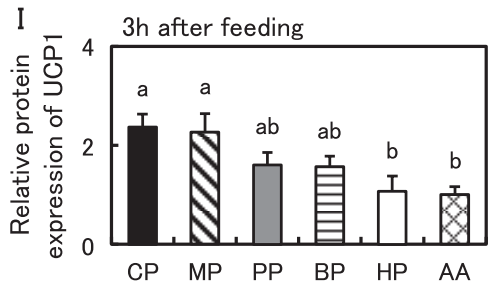

Fig. 3. Effects of meat protein diets (CP, chicken protein; MP, mutton protein; PP, pork protein; BP, beef protein; HP, horse meat protein) on the expression of thyroid hormone target genes and their translation products in rat BAT. A, relative expression of thyroid hormone-responsive Spot 14 protein (THRSP) mRNA; B, representative bands of THRSP; C, relative production of THRSP; D, relative expression of malic enzyme 1 (ME1) mRNA; E, representative bands of ME1 protein; F, relative production of ME1 protein; G, relative expression of uncoupling protein 1 (UCP1) mRNA; H, representative bands of UCP1 protein; I, relative production of UCP1 protein. Samples were collected at 1, 2, and $3 \mathrm{~h}$ after feeding for $1 \mathrm{~h}$. Values are normalized to $\beta$-actin. Values are means \pm SEM ( $n=6$ rats per group). Columns with different letters are significantly different ( $p<0.05$; Tukey's multiple comparison test).

HP and AA groups (Fig. 3H, I).

\section{DISCUSSION}

In this study, we compared the effects of purified meat proteins on postprandial thermogenesis and on the secretion of and responsiveness to thyroid hormones in rats. In order to reproduce the response in humans, we gave the rats experimental diets including not only the proteins but also other nutrients. Body temperatures measured at $2 \mathrm{~h}$ after feeding, when they had almost peaked, were higher in the CP and MP groups than in the other groups. The temperatures of the concha and rectum remained high even at $3 \mathrm{~h}$ after feeding in the MP group. In agreement with our previous results, CP and MP had stronger DIT-enhancing effects than those of the other proteins $(10,11)$. Therefore, the purified 
proteins contributed to differences in the effects of meat consumption on DIT. Although traditional Chinese medicine claims that horse meat "cools" the body (22, 23), its protein fraction had no DIT-suppressing effect. Since we could not clarify whether the consumption of horse meat cools the body, further studies are needed.

THs are likely to be involved in the enhancing effects of chicken and mutton on DIT $(10,11)$. Thus, different meat proteins may have different effects on the secretion of, or responsiveness to, THs. The level of Thrsp mRNA in BAT at $1 \mathrm{~h}$ after feeding was high in the MP group, in which there was a large DIT effect. The levels of THRSP in both the liver and BAT at $3 \mathrm{~h}$ after feeding were high in the $\mathrm{CP}$ and MP groups, in both of which there was a large DIT effect. The response of Thrsp to THs is so fast that its expression is regulated before that of other $\mathrm{TH}$ target genes; Thrsp regulates the expression of enzymes involved in subsequent lipid metabolism $(14,24,25)$. Thus, there may have been rapid transcriptional regulation of Thrsp by THs in the CP and MP groups, resulting in increased production of the proteins. The levels of Me1 mRNA in the liver and of ME1 protein in the liver and BAT at $3 \mathrm{~h}$ after feeding were high in the $\mathrm{CP}$ group. The expression of $\mathrm{Me} 1$ is regulated not only directly by THs but also indirectly by THRSP (14). Therefore, this biphasic transcriptional regulation of Me1 may have increased the production of the protein in the CP group. These results show that different meat proteins had different effects on THs and that in the $\mathrm{CP}$ and MP groups, in which there were large DIT effects, expression levels of TH target genes and their products were high. However, the levels of Me1 and ME1 were not high in the MP group. These results show that the effect of MP on THs is likely to be different from that of $\mathrm{CP}$.

Plasma $\mathrm{T}_{3}$ and $\mathrm{T}_{4}$ levels were not high in the $\mathrm{CP}$ and MP groups. $\mathrm{T}_{3}$ has high affinity for TH receptors in tissues, and $\mathrm{T}_{4}$ is converted to $\mathrm{T}_{3}$ through the action of deiodinase (Dio) (26). Thus, differences in the activity of Dio influence tissue responsiveness to THs. However, neither Dio1 mRNA (highly expressed in the liver (27)) nor Dio2 mRNA (highly expressed in BAT (28)) levels were high in the $\mathrm{CP}$ or MP groups (data not shown). Therefore, the enhancing effects of $\mathrm{CP}$ and MP on expression levels of TH target genes and their products likely resulted from the direct action of THs. Because the plasma $\mathrm{T}_{4}$ level in the CP group was significantly reduced between 1 and $2 \mathrm{~h}$ after feeding, the $\mathrm{T}_{4}$ level in the first hour after feeding was likely to have been higher. Feedback inhibition may already have acted, and differences among meat proteins in effects on THs or their target genes likely occurred in the first hour after feeding. Therefore, the expression levels of their translation products may have been high in the CP and MP groups.

Dorsal temperature was higher in the $\mathrm{CP}$ and MP groups than in the other groups. The level of UCP1 protein in BAT was high in the $\mathrm{CP}$ and MP groups. BAT is the only tissue in the body that functions only to produce heat, and UCP1 plays a key role in this mechanism. Because UCP1 is an uncoupling protein that converts the energy emitted during the oxidation process of the electron transport chain directly to heat (29-31), any difference in UCP1 action alters the amount of heat production. Previous studies have shown that an increase in $\mathrm{T}_{3}$ concentration enhances the promotive effect of noradrenaline on Ucp 1 mRNA expression in BAT in rats (17, 32-34). Thus, THs were very likely to have been involved in the regulation of levels of Ucp 1 mRNA and UCP1 protein in the CP and MP groups. The results suggest that thermogenesis by UCP1 in BAT played a major role in the DIT-enhancing effects of $\mathrm{CP}$ and MP and that THs were involved in this mechanism.

Our results did not show high body temperatures in the AA group. In recent years, many bioactive peptides have been identified in food protein digests, and it has been shown that peptides obtained through proteolysis play a role in biological regulation (35-37). For example, angiotensin 1-converting enzyme inhibitory peptides (38) and peptides with a plasma cholesterol-reducing effect (39) have been derived from soy protein. The amino acid compositions of meat proteins are similar, but the amino acid sequences might be different. Thus, digestion-derived peptides from meat proteins may vary, and this variation may affect how they influence DIT. Therefore, proteins or their digested peptides derived from CP and MP are assumed to contribute to DIT. However, from the fact that the effects of $\mathrm{CP}$ and MP on THs may be different, the $\mathrm{CP}$-derived peptides contributing to DIT may be different from those of MP. Further studies are needed to elucidate the mechanisms by which consumption of $\mathrm{CP}$ and MP raises body temperature.

\section{CONCLUSIONS}

The DIT-enhancing effects of meat proteins differ between animal species, and $\mathrm{CP}$ and MP have strong DIT effects. In addition, thermogenesis by UCP1 in BAT plays a major role in the strong DIT effects of $\mathrm{CP}$ and MP, and THs are involved in this mechanism. Because there is little difference in the amino acid composition of meat proteins from different animal species, proteins or their digested peptides may be involved in the strong DIT effects of CP and MP.

\section{REFERENCES}

1) Westerterp KR. 2004. Diet induced thermogenesis. Nutr Metab (Lond) 1: 5.

2) Scott CB, Devore R. 2005. Diet-induced thermogenesis: variations among three isocaloric meal-replacement shakes. Nutrition 21: 874-877.

3) Jequier E. 1983. Thermogenic responses induced by nutrients in man: their importance in energy balance regulation. Experientia 44: 26-44.

4) Karst H, Steiniger J, Noack R, Steglich HD. 1984. Dietinduced thermogenesis in man: thermic effects of single proteins, carbohydrates and fats depending on their energy amount. Ann Nutr Metab 28: 245-252.

5) Carlson GL. 1997. Nutrient induced thermogenesis. Baillière's Clin Endocrinol Metab 11: 603-615.

6) Diepvens K, Westerterp KR, Westerterp-Plantenga MS. 2007. Obesity and thermogenesis related to the consumption of caffeine, ephedrine, capsaicin, and green tea. Am J Physiol Integr Comp Physiol 292: R77-85. 
7) Westerterp-Plantenga M, Diepvens K, Joosen AMCP, Bérubé-Parent S, Tremblay A. 2006. Metabolic effects of spices, teas, and caffeine. Physiol Behav 89: 85-91.

8) Saito M, Yoneshiro T. 2013. Capsinoids and related food ingredients activating brown fat thermogenesis and reducing body fat in humans. Curr Opin Lipidol 24: 71-77.

9) Dulloo AG, Seydoux J, Girardier L, Chantre P, Vandermander J. 2000. Green tea and thermogenesis: interactions between catechin-polyphenols, caffeine and sympathetic activity. Int J Obes Relat Metab Disord 24: 252-258.

10) Wakamatsu J, Fujii R, Yamaguchi K, Miyoshi S, Nishimura T, Hattori A. 2013. Effects of meat species on the postprandial thermic effect in rats. Anim Sci J 84: 416-425.

11) Wakamatsu J, Takabayashi N, Ezoe M, Hasegawa T, Fujimura T, Takahata Y, Morimatsu F, Nishimura T. 2013. Postprandial thermic effect of chicken involves thyroid hormones and hepatic energy metabolism in rats. J Nutr Sci Vitaminol 59: 516-525.

12) Silva JE. Thermogenic mechanisms and their hormonal regulation. 2006. Physiol Rev 86: 435-464.

13) Kim B. 2008. Thyroid hormone as a determinant of energy expenditure and the basal metabolic rate. Thyroid 18: $141-144$.

14) Yen PM. 2001. Physiological and molecular basis of thyroid hormone action. Physiol Rev 81: 1097-1142.

15) Feng X, Jiang Y, Meltzer P, Yen PM. 2000. Thyroid hormone regulation of hepatic genes in vivo detected by complementary DNA microarray. Mol Endocrinol 14: 947-955.

16) Blennemann B, Leahy P, Kim TS, Freake HC. 1995. Tissue-specific regulation of lipogenic mRNAs by thyroid hormone. Mol Cell Endocrinol 110: 1-8.

17) Silva JE. 1988. Full expression of uncoupling protein gene requires the concurrence of norepinephrine and triiodothyronine. Mol Endocrinol 2: 706-713.

18) Rothwell NJ, Saville ME, Stock MJ, Wyllie MG. 1983. Influence of thyroid hormone on diet-induced thermogenesis in the rat. Horm Metab Res 15: 394-398.

19) Glick Z, Uncyk A, Lupien J, Schmidt L. 1989. Meal associated changes in brown fat thermogenesis and glycogen. Physiol Behav 45: 243-248.

20) Gabarrou JF, Duchamp C, Williams J, Géraert PA. 1997. A role for thyroid hormones in the regulation of dietinduced thermogenesis in birds. Br J Nutr 78: 963-973.

21) Kagawa Y. 2011. Standard Tables of Food Composition in Japan 2010. Kagawa Nutrition University Publishing Division, Tokyo (in Japanese).

22) Nihon chui shokuyo gakkai. 2009. Yaku-zen Handbook Seimi Table. Ryogen, Tokyo (in Japanese).

23) Kastner J. 2009. Chinese Nutrition Therapy: Dietetics in Traditional Chinese Medicine (TCM), 2nd ed. Thieme, New York.

24) Liaw CW, Towle HC. 1984. Characterization of a thyroid hormone-responsive gene from rat. J Biol Chem 259: 7253-7260.

25) Cunningham BA, Moncur JT, Huntington, JT, Kinlaw, WB. 1998. "Spot 14" protein: a metabolic integrator in normal and neoplastic cells. Thyroid 8: 815-825.

26) Gereben B, Zavacki AM, Ribich S, Kim BW, Huang SA, Simonides WS, Zeöld A, Bianco AC. 2008. Cellular and molecular basis of deiodinase-regulated thyroid hormone signaling. Endocr Rev 29: 898-938.

27) Galton VA, McCarthy PT, St Germain DL. 1991. The ontogeny of iodothyronine deiodinase systems in liver and intestine of the rat. Endocrinology 128: 1717-1722.

28) Obregon MJ, Ruiz de Ona C, Hernandez A, Calvo R, Escobar del Rey F, Morreale de Escobar G. 1989. Thyroid hormones and $5^{\prime}$-deiodinase in rat brown adipose tissue during fetal life. Am J Physiol Endocrinol Metab 257: E625-631.

29) Collin A, Cassy S, Buyse J, Decuypere E, Damon M. 2005. Potential involvement of mammalian and avian uncoupling proteins in the thermogenic effect of thyroid hormones. Domest Anim Endocrinol 29: 78-87.

30) Cannon B, Nedergaard J. 2004. Brown adipose tissue: Function and physiological significance. Physiol Rev 84: 277-359.

31) Gesta S, Tseng YH, Kahn CR. 2007. Developmental origin of fat: tracking obesity to its source. Cell 131: $242-256$.

32) Bianco AC, Branco M, Ribeiro M, Negra N. 1999. 3,5,3'-Triiodothyronine actively stimulates UCP in brown fat under minimal sympathetic activity. Am J Physiol-Endocrinol Metab 276: E179-187.

33) Obregón MJ, Calvo R, Hernández A, Escobar del Rey F, Morreale de Escobar G. 1996. Regulation of uncoupling protein messenger ribonucleic acid and 5'-deiodinase activity by thyroid hormones in fetal brown adipose tissue. Endocrinology 137: 4721-4729.

34) Rabelo R, Schifman A, Rubio A, Sheng X, Silva JE. 1995. Delineation of thyroid hormone-responsive sequences within a critical enhancer in the rat uncoupling protein gene. Endocrinology 136: 1003-1013.

35) Rizzello CG, Losito I, Gobbetti M, Carbonara T, De Bari MD, Zambonin PG. 2005. Antibacterial activities of peptides from the water-soluble extracts of Italian cheese varieties. J Dairy Sci 88: 2348-2360.

36) Fitzgerald RJ, Murray BA. 2006. Bioactive peptides and lactic fermentations. Int J Dairy Technol 59: 118-125.

37) Korhonen H, Pihlanto A. 2006. Bioactive peptides: Production and functionality. Int Dairy J 16: 945-960.

38) Kodera T, Nio N. 2006. Identification of an angiotensin I-converting enzyme inhibitory peptides from protein hydrolysates by a soybean protease and the antihypertensive effects of hydrolysates in spontaneously hypertensive model rats. J Food Sci 71: C164-173.

39) Wang W, Gonzalez De Mejia E. 2005. A new frontier in soy bioactive peptides that may prevent age-related chronic diseases. Compr Rev Food Sci Food Saf 4: 63-78. 